\title{
Suitability of modified low carbon Roman cements for architectural restoration
}

\author{
Myroslav Sanytsky ${ }^{1}$, Tetiana Kropyvnytska ${ }^{1}$, Roman Kotiv $^{2, *}$, Mykola Bevz $^{3}$, and Stanislav Fic ${ }^{4}$ \\ ${ }^{1}$ Department of Building production, Lviv Polytechnic National University, 12 Bandera St. 79013, Ukraine \\ 2Department of Architectural Design and Engineering, Lviv Polytechnic National University, 12 Bandera St. 79013, Ukraine \\ 3Department of Restoration of Architectural and Artistic Heritage, Lviv Polytechnic National University, 12 Bandera St. 79013, Ukraine \\ ${ }^{4}$ Department of Building Structures, Lublin University of Technology, 40 Nadbystrzycka str. 20-618, Poland
}

\begin{abstract}
Article is devoted to the investigation of suitability of low carbon Roman cement for restoration and finishing works. The history of the development of Roman cement as a natural hydraulic binder, which was commonly used to decorate building facades in the 19th and early 20th centuries, is presented. The properties of mortars based on Roman cement make it an excellent product for architectural restoration and conservation, as they are characterized by fast setting, high porosity typical for lime mortars, high resistance to weather conditions, high initial strength. At the same time, due to the high surface activity and increased water demand for cement, with the age of hardening, shrinkage deformations can develop, which leads to the formation of main cracks on the surface of the products. It is shown that the addition of gypsum is an effective regulator of the setting time of Roman cement and contributes to an increase in the strength of the cement paste. Analogs of Roman cement based on multicomponent cement binders modified with plasticizing and airentraining additives are presented.
\end{abstract}

\section{Introduction}

In accordance with the requirements of the Paris Agreement under the UN Framework Convention on Climate Change (UNFCCC) to regulate measures to reduce carbon dioxide emissions in construction, low-carbon ecocements will become increasingly important $[1,2]$. As a result of the ecological action of the cement industry in the direction of sustainable development, such low-carbon cements due to the choice of appropriate combinations of components become an alternative to conventional Portland cements [3-5].

In this regard, a significant practical interest is Roman cement, which is one of the stages of development of the technology of binders and has been widely used since the early nineteenth century. In 1796, James Parker [6] for the first time obtained a new brown cement, reminiscent of ancient Roman lime and pozzolana powders, and called it Roman cement when firing marl limestone with a significant content of clay impurities (30-35\%) taken from the slopes of Mount Kent (England). French chemist Louis Vicat noted that the calcined material (clinker) with a high content of $\mathrm{Al}_{2} \mathrm{O}_{3}$ and $\mathrm{SiO}_{2}$ has hydraulic properties. According to H. Kühl's [7] classification, the term "Roman lime" (Roman cement) covers a group of binders that are not considered burnt clinker, but also do not belong to lime due to the low content of free $\mathrm{CaO}$.
At the end of the 19th century (1890), the Journal of the Technical Society of Cracow published a definition of Roman cement, which stated that this material was obtained by not roast-sintering clay-limestone marls with subsequent grinding to a powdery state. The most famous English Roman cements were made of marl limestone with inclusions of clay or raw materials from Cretaceous or Jurassic formations. In France, marl deposits from the Jurassic regions of Burgundy and chalk near Grenoble were used. The main centers of Roman cement production were also Switzerland, Germany, the Czech Republic and Galicia. In the Western region of Ukraine (XIX-XX centuries) building mixes on the basis of Roman cement were widely used, namely not far from Lviv workshops were created for the production of various standard architectural details for finishing buildings on the basis of Roman cement. This material was called "Lviv Stone", which is very similar in texture and composition to natural stone, which was proved during a survey of existing architectural monuments in Lviv by specialists-restorers in recent years. However, after the end of World War I, Roman cement was rarely used, and later the technology of its production and finishing techniques were forgotten [8].

Today Roman cement is of considerable practical interest as a natural hydraulic binder for repair and restoration works. As part of the European project EUproject ROCARE "Roman cement for the restoration of architecture to new high standards" based on research by

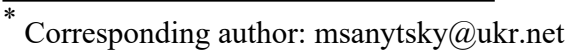


foreign scientists (J. Weber, C. Gosselin, R. Kozlowski, H. Szeląg, A. Garbacik) in Austria and Poland it is established research-industrial production of Roman cement, restored the technology of its manufacture, expanded the range of products based on it and created the possibility of using the material in the restoration market [9-13].

When mixed with water, Roman cement quickly setting and hardening compared to Portland cement. This is due to the formation of calcium hydrosilicates C-S-H (B), as well as tricalcium hydroaluminate $\mathrm{C}_{3} \mathrm{AH}_{6}$ and hydroferrites $\mathrm{C}_{3} \mathrm{FH}_{6}$. To regulate the properties of the composition of Roman cement during grinding, could be added up to 5\% gypsum of various modifications and up to $15 \%$ of active mineral additives. Roman cement-based mortars are characterized by rapid hardening, high porosity, which is also characteristic of lime mortars. Plasters based on such binders do not retain moisture in the walls of the building, which prevents the formation of cracks [14-16].

Roman cement is also used for the manufacture of paints for renovation of the surface of plasters and other decorative elements. Such paints are suitable for decoration, restoration and aesthetic integration of the facade and architectural elements, especially when applied to decorative elements with a wide range of details in the form of carvings or in cases where it is impossible to perform a thin layer (2-3 mm) of plaster. However, the lack of proper raw materials significantly complicates the production of Roman cement, and low production capacity leads to a significant increase in its cost [17].

At present, the production of Roman cement is established at the research and production plant of the Institute of Ceramics and Building Materials (Department of Glass and Building Materials in Krakow, Poland). Burning of Roman cement clinker takes place in rotary kilns measuring $1.25 \times 16 \mathrm{~m}$ at a temperature of $800-900^{\circ} \mathrm{C}$. During the burning of raw materials (natural marls) there is a dissociation of calcium and magnesium carbonate, which promotes the active passage of reactions in the solid state with the formation of the main phases of Roman cement calcium silicates $\beta-\mathrm{C}_{2} \mathrm{~S}$ (belite), calcium aluminates $\mathrm{CA}$ and $\mathrm{C}_{12} \mathrm{~A}_{7}$, ferrite $\mathrm{C}_{2} \mathrm{~F}$. High burning temperature (above $1000^{\circ} \mathrm{C}$ ) leads to overheating of raw materials with the formation of hydraulically inert mineral gehlenite $\mathrm{C}_{2} \mathrm{AS}$. However, the low burning temperature does not provide a full degree of material synthesis [18, 19].

In the production of Roman cement, the raw material mixture is burning in the form of granules. The firing temperature in the inner part of the clinker and on its surface is not the same, which prevents the achievement of an equilibrium reaction. The reaction between silica and alumina occurs only in areas of maximum burning temperatures. Highly reactive phases such as $\mathrm{CA}, \mathrm{C}_{12} \mathrm{~A}_{7}$, formed on the surface of clinker granules without the presence of glass phase, determine the rapid hardening and strength in the early stages, and with age of hardening, the increase in strength occurs due to hydration of the belite phase. Fine binder also provides pozzolanic reaction in addition to hydraulic that allows improving construction and technical properties of Roman cement (Fig. 1). The hydration of the cements studied was shown to comprise two distinct stages. The immediate setting and early strength is due to the formation of calcium aluminum oxide carbonate (or sulfate) hydroxide hydrates. The development of long-term strength is brought about by the formation of calcium silicate hydrates [20].

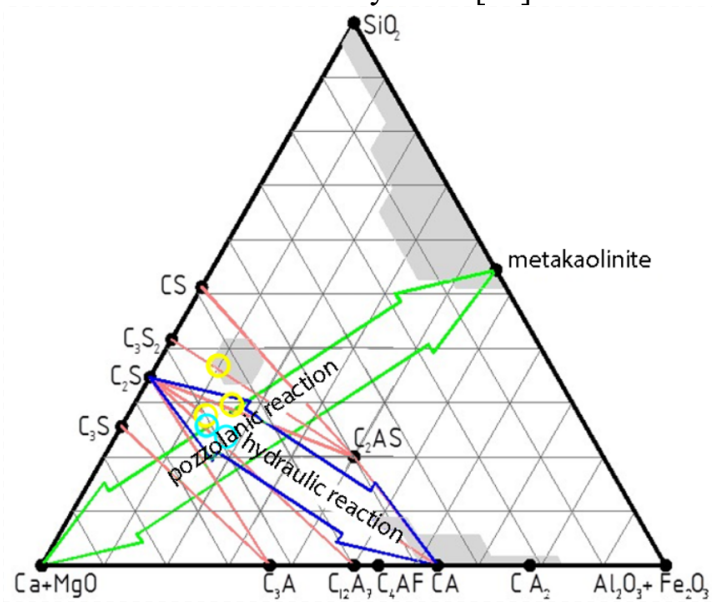

Fig. 1. Hydraulic and pozzolanic reactivity of Roman cement (according to Wolter [20]).

Roman cement is characterized by increased water consumption and rapid hardening as well as shrinkage $[21,22]$. There are rapid and slow hardening types of Roman cement. For Roman cement with the initial hardening time not more than 15 minutes, the compressive strength should be not less than 6.0 MPa.

The addition of lime does not retard Roman cement hydration, therefore retardation of Roman cement is essential in hybrid mortars. Lime permits fine control of mortar (workability, workable life, strength). This results indicate a wider potential for render applications in general. If the Roman cement is retarded by means of a prehydration process, hybrid mortars can be produced with improved workability and workable life as well as permitting the fine control of strength and moisture transport [23].

Roman cement's compositions modified by chemical and mineral additives have been proposed [24]. Plasticizers and hardening accelerators were chosen and used that allowed rising the durability up to $35 \mathrm{MPa}$ relatively. Superplasticizers and air-repellent additives help to reduce the amount of water, increase water resistance and durability. Mineral additives like slag, zeolite tuff and clay dust were chosen and used that rise the strenght from 22 to $28 \mathrm{MPa}$. In this case, Roman cement with zeolitecontaining mineral additive in a dosage of $15-16 \%$, shows maximum strength.

On the other hand, of considerable practical interest is the development of substitutes for Roman cement with appropriate physical and mechanical properties and plasters based on them. With the introduction of mineral additives of different types, it is possible to obtain a low$\mathrm{CO}_{2}$ multicomponent cements [25-27]. To accelerate the processes of early structure formation, it is advisable to use alkaline activation [28, 29]. Of particular note are decorative multi-component alkali activated cements for restoration and finishing works, which are chemically analogous to Roman cement [30]. Such multicomponent cements, modified with complex admixtures plasticizing and air-absorbing action, have comparable or even better performance compared to Roman cement and allow allow 
to use them successfully in making plasters, mortars. for restoration, finishing works and decoration of facades. Promising direction for improving the properties of multicomponent binders is nanomodification in combination with nanosilica [31, 32].

At the same time, Roman cement plays an important role in the technology of restoration work. Therefore, the task is to study the features of the processes of structure formation and the formation of the properties of Roman cement for its suitability and increasing the operational properties.

\section{Materials and methods of research}

\subsection{Materials}

Roman cement was used in experimental research (IMMB, Poland). The chemical composition of Roman cement is respectively 51.1 wt. $\% \mathrm{CaO} ; 33.0$ wt. $\% \mathrm{SiO}_{2} ; 8.54$ wt.\% $\mathrm{Al}_{2} \mathrm{O}_{3} ; 2.34$ wt. $\% \mathrm{Fe}_{2} \mathrm{O}_{3} ; 2.01$ wt. $\% \mathrm{MgO} ; 1.33$ wt. $\% \mathrm{~K}_{2} \mathrm{O}$; 0.4 wt. $\% \mathrm{Na}_{2} \mathrm{O} ; 0.87$ wt. $\% \mathrm{SO}_{3} ; 12.33$ wt. \% LOI.

As can be seen from Fig. 2, on the X-ray powder diffraction patterns of non-hydrated Roman cement, in addition to the lines of basic clinker minerals $\beta-\mathrm{Ca}_{2} \mathrm{SiO}_{4}$ $\left(\beta-\mathrm{C}_{2} \mathrm{~S}\right)$ and $\mathrm{CaAl}_{2} \mathrm{O}_{4}(\mathrm{CA})$, lines of calcite $\mathrm{CaCO}_{3}$ $(\mathrm{d} / \mathrm{n}=0.303 ; 0.277 ; 0.208 ; 1.912 \mathrm{~nm})$, quartz $\beta-\mathrm{SiO}_{2}$ $(\mathrm{d} / \mathrm{n}=0.424 ; 0.334 ; 0.249 ; 0.228 \mathrm{~nm})$ and gehlenite $\mathrm{Ca}_{2} \mathrm{Al}(\mathrm{Al}, \mathrm{Si}) \mathrm{O}_{7}(\mathrm{~d} / \mathrm{n}=0.285 ; 0.176 \mathrm{~nm})$ are additionally displayed. The content of $\mathrm{SiO}_{2}$ and $\mathrm{CaCO}_{3}$ is 10 and 25 wt.\%, which indicates the incomplete nature of the reactions of solid-phase synthesis of clinker minerals of Roman cement.

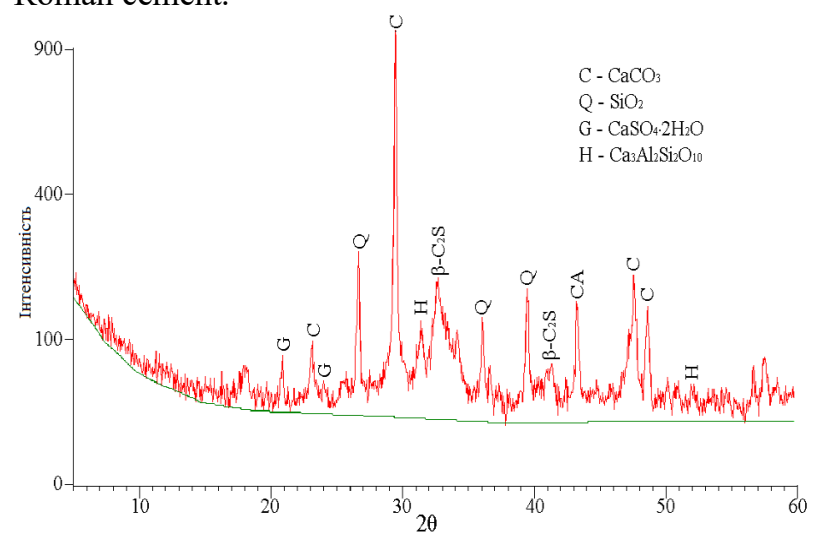

Fig. 2. X-ray powder diffraction patterns of non-hydrate Roman cement.

Roman cement is a decorative binder (the reflection coefficient of the degree of whiteness is $60 \%$ ).

\subsection{Methods}

Determination of physical (average density, porosity, water absorption), physical and mechanical properties of Roman cement was carried out according to standard methods. The study of the phase composition of cement hydration products was performed using a set of modern physical and chemical methods of analysis: X-ray diffractometry (DRON-2.0, Siemens D5000), differential thermography (OD-1500Q), and mercury porometry
(Autopore II 9220). The chemical compositions of cements and mineral additives were determined by an ARL OPTIM'X X-ray spectrometer. Calorimetric studies of hydrated cement samples were performed using a Zwick Roel calorimeter. Philips XL30 ESEM-FEG and REM106I scanning electron microscopes were used to study the morphology of the paste surface on the basis of decorative cements and plasters. Fineness of cementitious materials was characterized by the spesific surface area using the Blaine air permeability test. Particle-size distribution was studied with the help of laser high-resolution particle size analyzer Mastersizer 3000.

\section{Research results}

It was established by the method of laser granulometry (Fig. 3), that for Roman cement $\left(\mathrm{SSA}=800 \mathrm{~m}^{2} / \mathrm{kg}\right.$; $\left.\mathrm{A}_{008}=4.0 \%\right)$ the content of fractions $\varnothing 1 ; \varnothing 10 ; \varnothing 20$ and $\varnothing 60 \mu \mathrm{m}$ is $14.5 ; 48.7 ; 59.4$ and $88.3 \%$ respectively. The grain size of D10; D50 and D90 correspond to $0.79 ; 11.8$ and $69.61 \mu \mathrm{m}$.

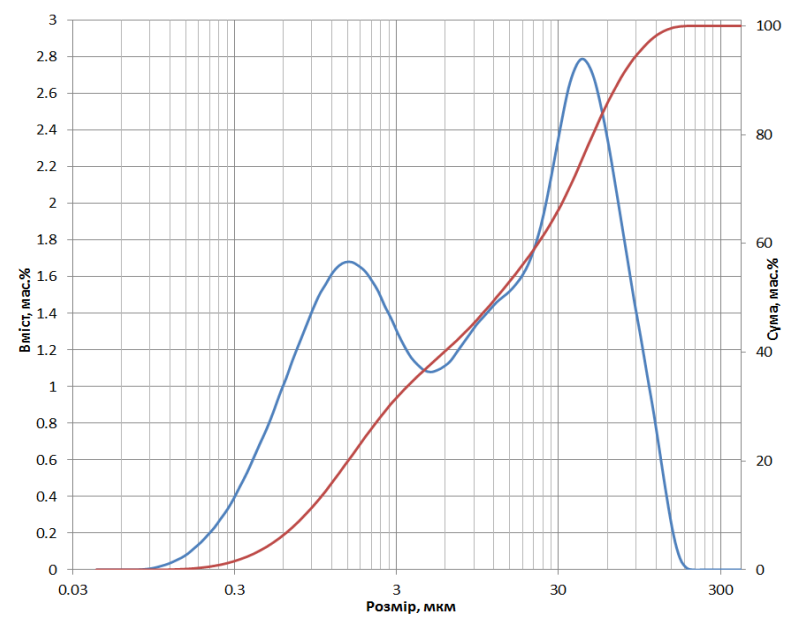

Fig. 3. Particle size distribution of Roman cement.

Based on the granulometric analysis data, the differential surface activity coefficient ( $\left.\mathrm{K}_{\text {isa }}\right)$ was calculated. This coefficient is defined as the $\mathrm{A} / \mathrm{V}$ multiplication for a given particle size (ratio of particle surface area to volume, $\mu \mathrm{m}^{-1}$ ) by the volume content of each material fraction, based on laser-determined graining data [33]. The $\mathrm{K}_{\text {isa }}$ value determines the surface activity of a given particle size in the set of cement grains. Thus, the development of the specific surface is determined by the contribution of small fractions and the maximum value of $\mathrm{K}_{\text {isamax }}=10.0 \mu \mathrm{m}^{-1} \mathrm{vol} . \%$ is achieved for the fraction of 0.6 $\mu \mathrm{m}$, while for the fraction of $42.0 \mu \mathrm{m}$ with a maximum content of particles $(2.8 \mathrm{wt} \%) \mathrm{K}_{\text {isa }}$ is only $0.43 \mu^{-}$ ${ }^{1}$ vol. $\%$.

As can be seen from Fig. 4, the contribution of small fractions to the development of the specific surface is decisive. The high dispersion of such particles largely determines their surface energy and leads to a significant water demand of the binder.

Calorimetric analysis (Fig. 5) showed that the Roman cement is characterized by a short induction period ( $\tau=12$ 
min) and low heat of hydration $(29.8 \mathrm{~J} / \mathrm{g})$, while the exoeffect is $31.6 \mathrm{cal} /(\mathrm{gh})$.

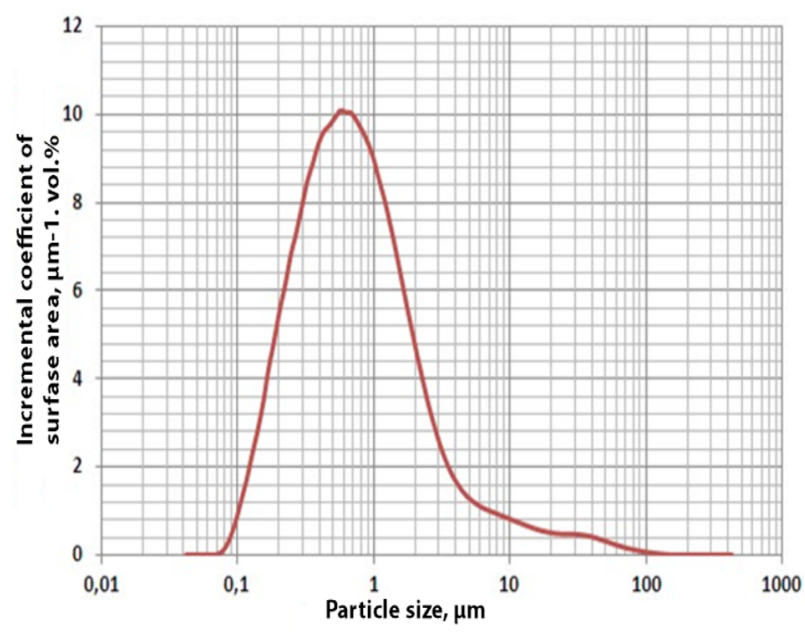

Fig. 4. Differential coefficient of surface activity of Roman cement.

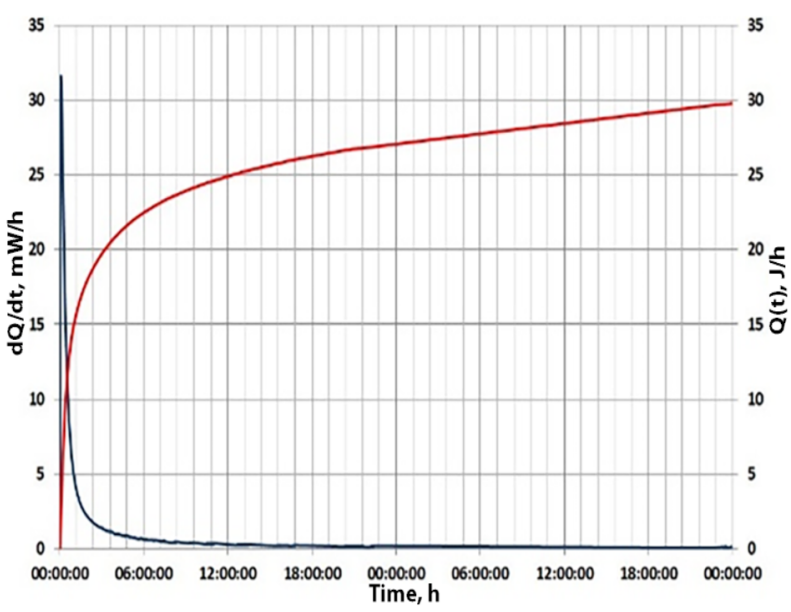

Fig. 5. Kinetics of Roman cement heat release.

Highly reactive phases such as $\mathrm{CA}, \mathrm{C}_{12} \mathrm{~A}_{7}$ determine the rapid hardening and strength in the early stages, and with age of hardening, the increase in strength occurs due to hydration of the belite phase. Initial and final setting time of the cement (water demand - 0.40) is 3 and 8 minutes, respectively, and the strength of the paste after $1 ; 3 ; 7$ and 28 days of hardening is $4.9 ; 6.1 ; 7.6$ and 20.8 $\mathrm{MPa}$ respectively. For fresh cement-sand mortar $(\mathrm{C}: \mathrm{S}=1: 3)$ based on Roman cement the workability (consistence by flow table) $-115 \mathrm{~mm}(\mathrm{~W} / \mathrm{C}=1.0)$; in this case standard compressive strength of $10 \mathrm{MPa}$ is reached.

Roman cement mortars are characterized by exceptionally accelerated hardening time, which causes difficulties in plastering. Addition of 1.0 mass. $\%$ citric acid to Roman cement $(\mathrm{W} / \mathrm{C}=0.47$; workability -113 $\mathrm{mm}$ ) allows to delay initial setting time for $40 \mathrm{~min}$, while the compressive strength after 7 and 28 days is 4.93 and $21.8 \mathrm{MPa}$, respectively.

In order to establish the physicochemical laws of the formation of the structure and synthesis of the strength of Roman cements, the influence of gypsum was studied. For Roman cement paste, water consistency is achieved at
$\mathrm{W} / \mathrm{C}=0.40$, initial and final setting time are respectively 3 and $8 \mathrm{~min}$, the compressive strength after 3; 7 and 28 days is $6.1 ; 7.6$ and $20.8 \mathrm{MPa}$ (Table 1). Addition of 5 mass.\% gypsum dihydrate can reduce the water consumption by $17.5 \%$, while the initial and final setting time is delayed, and the compressive strength of the paste after $3 ; 7$ and 28 days of hardening increases by $4.5 ; 4.8$ and 2.7 times.

Table 1. Influence of gypsum dihydrate on the strength of Roman cement paste.

\begin{tabular}{|c|c|c|c|c|c|c|c|c|}
\hline \multirow{2}{*}{$\begin{array}{c}\text { Gypsum } \\
\text { additive, } \\
\text { mass.\% }\end{array}$} & W/C & \multicolumn{2}{|c|}{$\begin{array}{c}\text { Setting time, } \\
\text { h-m }\end{array}$} & \multicolumn{5}{|c|}{$\begin{array}{c}\text { Compressive strength, MPa, } \\
\text { in the age, days }\end{array}$} \\
\cline { 3 - 9 } & & initial & final & 1 & 3 & 7 & 21 & 28 \\
\hline- & 0,40 & $0-03$ & $0-08$ & 4,9 & 6,1 & 7,6 & 14,0 & 20,8 \\
\hline 5,0 & $0,40^{*}$ & $0-20$ & $0-24$ & 4,5 & 19,4 & 32,5 & 38,2 & 44,5 \\
\hline 5,0 & 0,33 & $0-16$ & $0-19$ & 10,8 & 27,5 & 37,0 & 49,8 & 55,6 \\
\hline
\end{tabular}

As can be seen from Fig. 6, the hydration of the Roman cement takes place in two stages: the first is the hydration of the aluminate phase, due to which the Roman cement sets quickly and gains strength in the initial curing period, in the second stage the belite phase provides strength gain at a later curing time. Due to the significant water-reducing effect $(\Delta \mathrm{W} / \mathrm{C}=45 \%)$ of the Roman cement with the addition of gypsum dihydrate, the strength of the binder after 28 and 90 days of hardening is increased by 2.2 and 2.4 times, respectively, compared to the Roman cement without additives.

This indicates that the use of gypsum dihydrate and retarding additives allows to change the course of the processes of structure formation, which determines further studies of their effect on the phase composition and microstructure of the Roman cement. Peculiarities of Roman cement hydration processes were studied by methods of physical and chemical analysis.

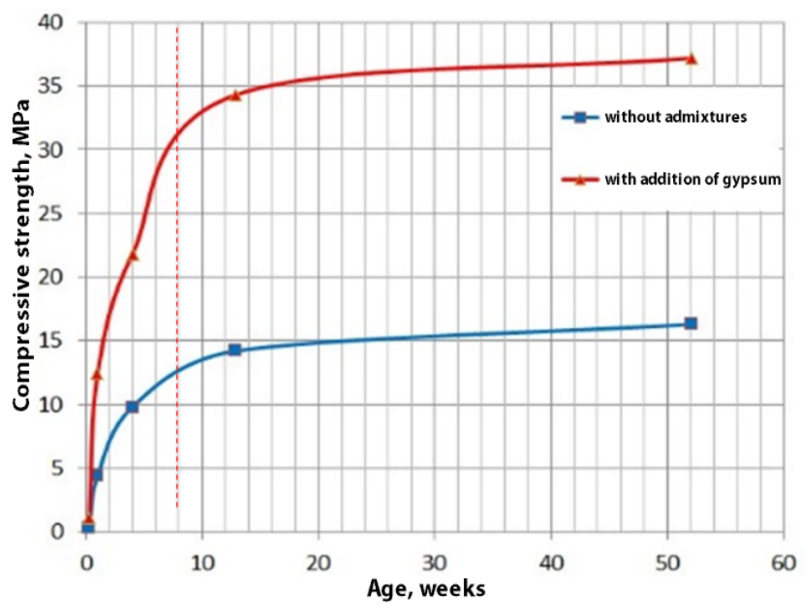

Fig. 6. Strength of Roman cement paste with age of hardening.

After 28 days of hydration, the calcium hydrocarboaluminate lines $\mathrm{C}_{3} \mathrm{~A} \cdot \mathrm{CaCO}_{3} \cdot 12 \mathrm{H}_{2} \mathrm{O}(\mathrm{d} / \mathrm{n}=0.761$; $0.380 \mathrm{~nm}$ ) are additionally observed on the diffractograms and the lines of portlandite are practically absent (Fig. 7). For Roman cement paste with the addition of gypsum, the newly formed hydrated phases of etringite $(\mathrm{d} / \mathrm{n}=0.973$; $0.561 ; 0.469 \mathrm{~nm})$ and hydrocalumite $(\mathrm{d} / \mathrm{n}=0.82 \mathrm{~nm})$ are 
observed. To calculate the degree of hydration, $\beta-\mathrm{C}_{2} \mathrm{~S}$ $(\mathrm{d} / \mathrm{n}=0.218 \mathrm{~nm})$ was used as the analytical line. It was found that for Roman cement after 28 days of curing, the degree of hydration is $71.0 \%$.

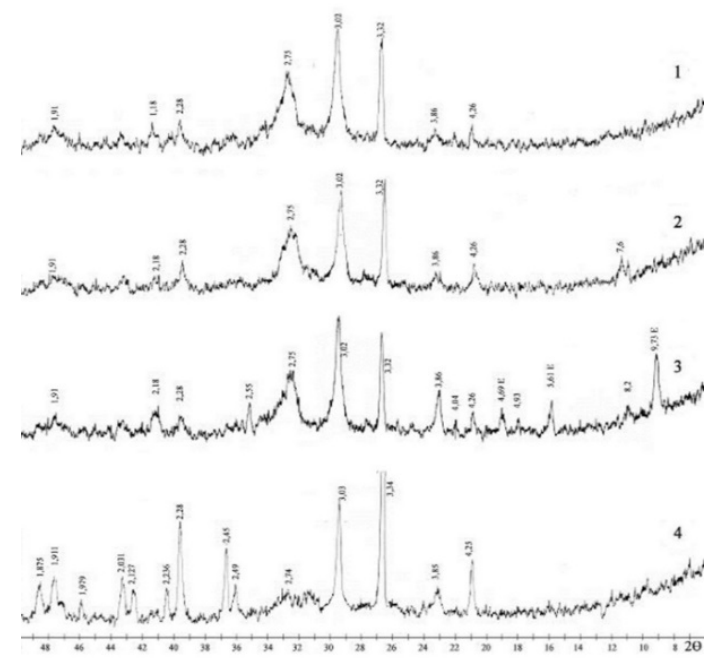

Fig. 7. Diffractograms of hydrated Roman cement paste at 28 days: 1 - non-hydrated; 2 - hydrated without additives; 3 hydrated with the addition of gypsum; 4 - from a decor element.

According to the thermal analysis (Fig. 8), it was found that for Roman cement with the addition of gypsum, the DTA curve recorded the endothermic effect at $125^{\circ} \mathrm{C}$, which corresponds to the release of water from calcium hydrosulfoaluminates. The DTA curve also shows an endoeffect in the temperature range of 600$850^{\circ} \mathrm{C}$ due to the decomposition of hydroaluminates and calcium carbonate. According to thermogravimetry (TG), the total weight loss during calcination for Roman cement with the addition of gypsum is $34.8 \%$.

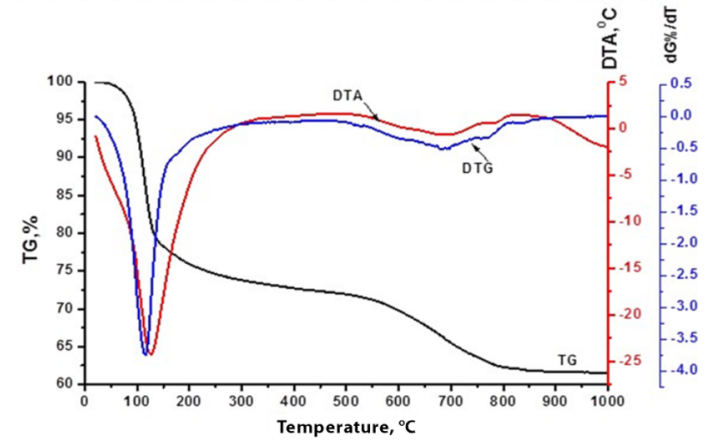

Fig. 8. Derivatograms of Roman cement, hydrated 90 days.

The method of scanning electron microscopy shows (Fig. 9) that the Roman cement, hydrated at 28 days, is characterized by a porous structure with a large number of open capillary pores. The formation of small crystals of calcium hydroaluminates $(\mathrm{C}-\mathrm{A}-\mathrm{H})$ is observed on the pore surface. The addition of gypsum allows to compact the structure of the Roman cement paste by colmatation the open pores with AFt-phases. According to the data of microprobe X-ray spectral analysis, the relative elemental composition of the pore surface shell corresponds to the main components of Roman cement clinker, mass.\%: Ca - 40.59; Al - 16.8; $\mathrm{Si}$ - 16.6; Fe - 0.6; $\mathrm{O}-36.8$. The surface of the pores is formed from the nuclei of crystals, as a result of which the capillary pulling of water and water absorption of the Roman cement paste are reduced.
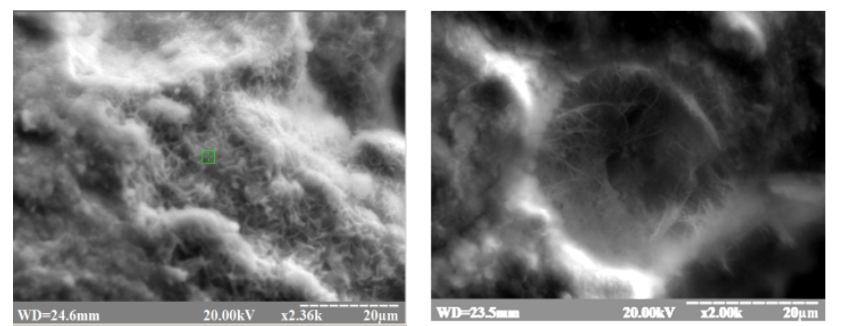

a
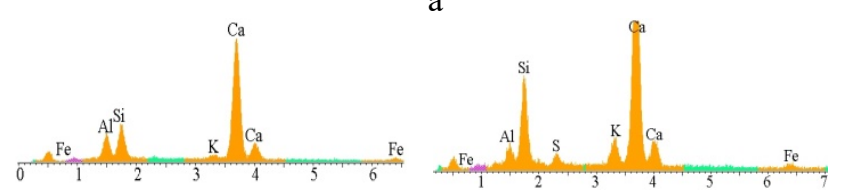

b
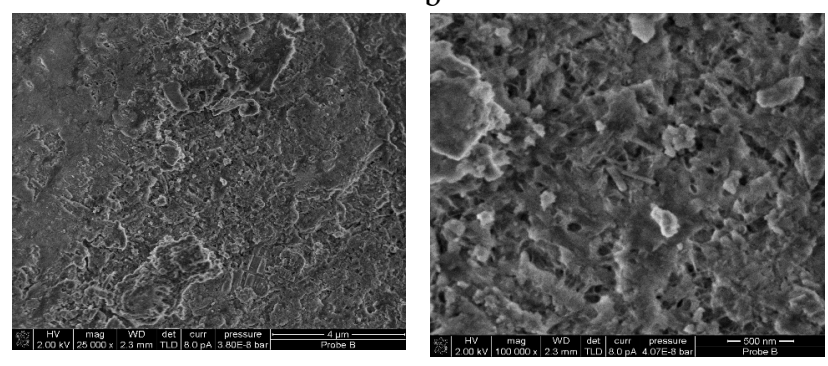

c

Fig. 9. Microstructure of Roman cement paste: a, c - at 28 and 360 days; $b$ - X-ray spectra from the surface of pore at 28 days.

Roman cement is characterized by significant porosity. Thus, for a paste based on Roman cement without additives, the total porosity is $41.0 \%$ (open $19.0 \%$, closed $-22.0 \%$ ). Addition of gypsum into the Roman cement allows to reduce the total porosity to $37.78 \%$, while the open porosity is reduced to $11.78 \%$ (Fig. 10). [89, 133].

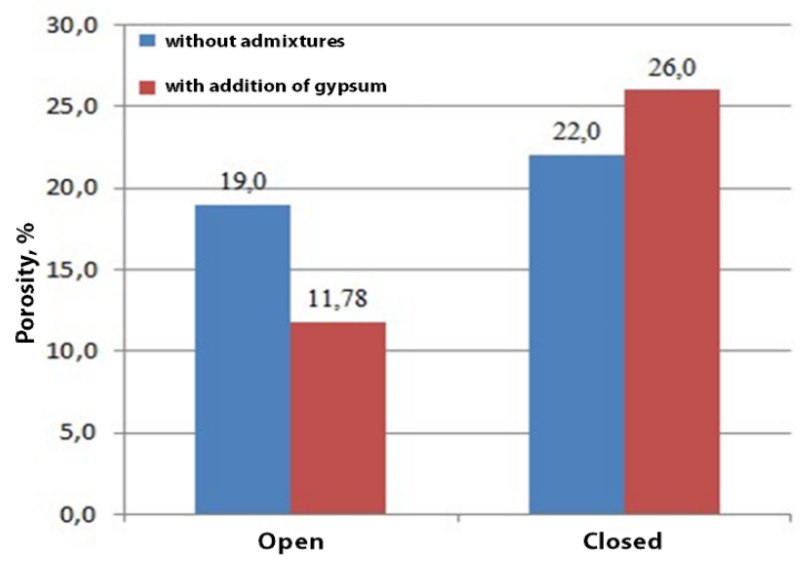

Fig. 10. Open and closed porosity of Roman cement paste.

Among the factors that determine the strength of the paste, of particular interest are the processes of destruction of its structure. Visual observations for a sample based on Roman cement (Fig. 11, a) after 1 year of curing show hair cracks covering the entire volume of 
the sample. The photomicrograph shows (Fig. 11, b) that the destruction of the material can cause main cracks, one of which is characterized by a width of $3.31 \mu \mathrm{m}$, the formation of which is due to the union of closed scaly submicroscopic micro cracks in the crystalline aggregates and between them, which is the reason of deformations of shrinkage of a Roman cement.

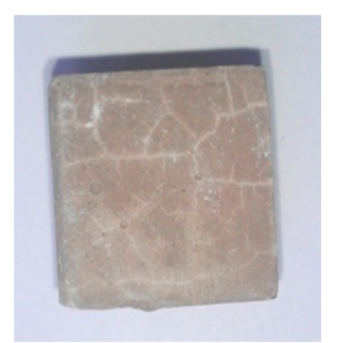

a

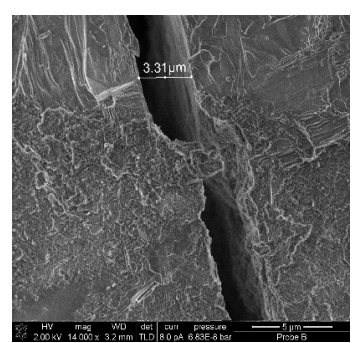

b
Fig. 11. The nature of the destruction of Roman cement, hydrated for 1 year: a - hair cracks in the sample; $\mathrm{b}$ - micrograph of shrinkage crack (x14000).

The peculiarities of chemical and mineralogical composition and high dispersion of Roman cement determine a significant increase in its water consumption, which leads to increased porosity of artificial stone, the formation of various cracks and possible peeling of plaster.

At the same time, despite many of its advantages, Roman cement is currently not widely used, and its production is low-tonnage, which determines its high cost. This is due to the relatively rare deposits of the raw material, which must have fine intergrowths of calcium carbonate and hydraulic components in the correct proportion. In addition, there are currently not enough low heat shaft kilns that are suitable kilns for the production of Roman cement.

\section{Conclusions}

1. The peculiarities of the chemical and mineralogical composition of Roman cement are revealed and its influence on the processes of hydration and hardening are established. High dispersion ( $\mathrm{SSA}=800 \mathrm{~m}^{2} / \mathrm{kg}$ ) and surface activity of Roman cement lead to an increase in its water demand.

2. The increased content of the highly reactive aluminate phase $\left(\mathrm{CA}, \mathrm{C}_{12} \mathrm{~A}_{7}\right)$ in the Roman cement determines the fast setting (initial and final setting time 3 and $8 \mathrm{~min}$, respectively) and strength in the early stages of hardening; the increase in strength with age of hardening (strength at 28 days is $10 \ldots 20 \mathrm{MPa}$ ) is achieved by hydration of the belite phase. After 1 year of hardening, main cracks may develop in the Roman cement paste due to deformation of the shrinkage.

3 . The addition of gypsum is an effective regulator of the setting time, and also reduces water consumption, which leads to an increase in the strength of the Roman cement paste.

\section{References}

1. CEMBUREAU, The role of cement in the 2050 low carbon economy. 64, (2013)

2. S. A. Miller, V. M. John, S. A. Pacca, and A. Horvath, Carbon dioxide reduction potential in the global cement industry by 2050. Cement and Concrete Research. 114, 115-124, (2018)

3. M. Schneider, The cement industry on the way to lowcarbon future. Cement and Concrete Research. 124, 1-19, (2019)

4. Sanytsky M., Kropyvnytska T., Fic S., Ivashchyshyn, H. Sustainable low-carbon binders and concretes. E3S Web of Conferences, 2020, 166, 06007

5. V.A Abyzov, K.K. Pushkarova, M. O. Kochevykh, O.A. Honchar, N.L. Bazeliuk, Innovative building materials in creation an architectural environment. IOP Conf. Series: Materials Science and Engineering 907, 012035 (2020).

6. Parker J.: Brit. Pat. No 2120, London 1796.

7. Kuhl H. Zement-Chemie. Verlag Technik. Berlin, 1952; dito. 2. Aufl. 1958.

8. Znachko-Yavorsky I. L. Essays on the history of binders from ancient times to the mid-nineteenth century. Moscow, 1963. - 497 p.

9. Wolter A. Belite cements and low-energy clinker. Cement International / 2007. - №1. - P. 64-73.

10. T. Baran, A. Garbacik, P. Pichniarczyk, H. Szeląg Cement romański i jego właściwości. Surowce i maszyny budowlane, 2008. - №1.

11. H. Szeląg, A. Garbacik, P. Pichniarczyk, T. Baran. Contemporary Roman cement and its properties. Civil Engineering. Krakow Polytechnic. 2009. Issue 9. - P. 357-345.

12. Hughes D.C., Jaglin D., Kozłowski R., Mucha D. Roman cements - Belite cements calcined at low temperature. Cement and Concrete Research, 39, 2009. - P. 77-89.

13. D. Hughes, S.Swann, A. Gardner. Roman Cement: Part One: Its Origins and Properties. Journal of Architectural Conservation, Vol.13, 2007 - Issue 1.

14. Hughes, D.C., Swann, S. and Gardner, A., 2007. Roman cement - Part Two: Stucco and decorative elements, a conservation strategy. Journal of Architectural Conservation 13 (3) 41-58.

15. Kozlowski R., Hughes D., Weber J. Roman cements - key materials of the built heritage of the nineteenth century. Technologies and Practice in Historic Heritage Structures. - Springer, Berlin. 2010

16. C. Gosselin, V. Vergès- Belmin, A. Royer, G. Martinet. Natural cement and monumental restoration. Materials and Structures. - 2009, № 42. - P. 749-763

17. Gosselin C., Scrivener K.L., Feldman S.B. Hydration of roman cements used for architectural restoration. 2-nd Historic Mortars Conference \& Rilem TC 203RHM Repair Mortars for Historic Masonry - Prague. - 2010, p. 993-1004. 
18. D. Wilk, Ł. Bratasz and R. Kozłowski. Reducing shrinkage cracks in Roman cement renders. 2-nd Historic Mortars Conference \& Rilem TC 203-RHM Repair Mortars for Historic Masonry. Prague. - 2010, $14 \mathrm{p}$.

19. R. Vyskocilova, W. Schwarz, D. Mucha, D. Hughes, R. Kozłowski, and J. Weber. Hydration Processes in Pastes of Roman and American Natural Cements. Journal of ASTM International, Vol. 4, No. 2 (2016). Paper ID JAI100669

20. D. C. Hughes, J. Weber and R. Kozlowski. Roman Cement for the Production of Conservation Mortars. Preprints of 2nd Historic Mortars Conference \& Rilem TC 203-RHM Repair Mortars for Historic Masonry Final Workshop, Prague, 22-24.08.2010.

21. Klisinska-Kopacz, A., Tislova, R., Adamski, G. and Kozlowski, R., Pore structure of historic and repair Roman cement mortars to establish their compatibility. Journal of Cultural Heritage 11 (4) 404-410.

22. Tišlova R., Kozłowska A., Kozłowski R., Hughesc D. Porosity and specific surface area of Roman cement pastes. Cement and Concrete Research Vol. 39, Issue 10, 2009, P. 950-956

23. V.Starinieri, D.C.Hughes, D.Wilk. Influence of the combination of Roman cement and lime as the binder phase in render mortars for restoration. Construction and Building Materials. Vol. 44, 2013, P. 192-199

24. Shelikhov N. and Sagdiyev R. Modified roman cements. IOP Conf. Series: Materials Science and Engineering 890 (2020) 012097

25. Sakhno, S., Yanova, L., Pischikova, O. Study of the influence of properties of dusty ferromagnetic additives on the increase of cement activity. The International Conference on Sustainable Futures: Environmental, Technological, Social and Economic

26. A.A. Plugin, O.S. Borziak, O.A. Pluhin, T.A. Kostuk, D.A. Plugin, Hydration products that provide waterrepellency for portland cement-based waterproofing compositions and their identification by physical and chemical methods. Lecture Notes in Civil Engineering 100, 328-335 (2020). 10.1007/978-3030-57340-9_40

27. Y. Savchuk, A. Plugin, V. Lyuty, O. Pluhin, O. Borziak. Study of influence of the alkaline component on the physico-mechanical properties of the low clinker and clinkerless waterproof compositions. MATEC Web of Conferences 230, 03018 (2018). doi: 10.1051/matecconf $/ 201823003018$

28. V. Gots, A.Gelevera, O. Petropavlovsky, N. Rogozina, V. Smeshko. Influence of whitening additives on the properties of decorative slagalkaline cements. IOP Conf. Series: Materials Science and Engineering 907, 012033

29. P. Krivenko, O. Petropavlovskyi, I. Rudenko, O. Konstantynovskyi, A. Kovalchuk. Complex multifunctional additive for anchoring grout based on alkali-activated portland cement. IOP Conference Series 907, 012055
30. P. Krivenko, M. Sanytsky, T. Kropyvnytska, R. Kotiv. Decorative multi-component alkali activated cements for restoration and finishing works. Advanced Materials Research 897, 45-48 (2014)

31. P. Sikora, D. Lootens, M. Liard, D. Stephan, Applied Nanoscience, 1-18 (2020).

32. K Skoczylas, T Rucińska. Cement-Wapno-Beton, 3, 206-215 (2018)

33. M. Sanytsky, A. Usherov-Marshak, T. Kropyvnytska, I. Heviuk. Performance of multicomponent Portland cements containing granulated blast furnace slag, zeolite, and limestone. Cement Wapno Beton, 25(5), (2020), 416-427 